\title{
PENGEMBANGAN TEKNOLOGI PRODUKSI TANAMAN BERKELANJUTAN
}

\section{Sudirman Yahya}

Guru Besar Tetap Fakultas Pertanian Institut Pertanian Bogor

\begin{abstract}
Abstrak
Teknologi produksi tanaman berkelanjutan haruslah yang mampu: (1) meningkatkan daya adaptasi tanaman terhadap cekaman kekeringan dan ketersediaan hara yang rendah, dan genangan, (2) membenahi sifat-sifat tanah yang menjadi faktor-faktor pembatas tersebut, yakni dengan memperbaiki kemampuan tanah menahan air dan kapasitas tukar kation, serta meningkatkan ketersediaan hara bagi tanaman, dan (3) mengefisienkan penggunaan input yang berbahan baku "non renewable resources" sebagai energi budi daya. Beberapa prioritas penelitian perlu dikemukakan sebagai upaya mempersiapkan teknologi budi daya agar tanaman mampu beradaptasi terhadap cekaman lingkungan tersebut.

Kajian respon fisiologi tanaman terhadap cekaman dapat diungkap dengan melibatkan beberapa genotipe tanaman yang mempunyai kemampuan berbeda dalam adaptasi terhadap cekaman lingkungan. Pada kajian tersebut biasanya dapat diperoleh karakter morfologi dan fisiologi yang menjadi pembeda tingkat toleransi atau kemampuan adaptasi, sekaligus mekanismenya. Karakter-karakter tersebut selain dapat digunakan sebagai karakter seleksi genotipe yang kita inginkan, juga sangat penting dalam pengembangan teknologi produksi yang dapat memperbaiki atau mengurangi pengaruh cekaman lingkungan tersebut.

Pengembangan teknologi produksi dapat dilakukan dengan pemanfaatan sumber daya alam mikroorganisme tanah melalui perbaikan lingkungan abiotik, interaksi faktor lingkungan abiotik dan biotik. Keramahan sumber daya alam berupa fenomena perbedaan tingkat toleransi terhadap cekaman dan keberagaman sumber daya tumbuhan dapat pula dimanfaatkan bagi pengembangan teknologi produksi. Femanfaatan keramahan sumber daya alam perlu pula
\end{abstract}


mempertimbangkan aspek efisiensi melalui pengembangan teknologi optimasi penggunaannya.

Kata Kunci: fisiologi cekaman, teknologi produksi tanaman berkelanjutan.

\section{Pemanfaatan SDA Mikroorganisme Tanah}

Teknologi perbaikan lingkungan abiotik. Mikroorganisme tanah (antara lain mikoriza, bakteri penambat $\mathrm{N}$, bakteri pelarut fosfat). Beberapa penelitian dan pengembangan sudah menunjukkan besarnya peranan mikroba tanah, baik secara mandiri, maupun bersimbiosis dengan tanaman dan atau dengan mikroorganisme lainnya. Peranan dapat berupa perbaikan dalam penyediaan hara dan penyerapannya oleh akar, serta dapat pula meningkatkan penyerapan air pada keadaan cekaman kekeringan.

Di wilayah Papua Barat (Kabupaten Sorong Selatan) terdapat sumber daya alam berupa deposit fosfat alam krandalit yang telah ditemukan oleh pemerintah kolonial Belanda. Lokasi endapan fosfat alam di Papua terdapat di Distrik Ayamaru, Kabupaten Sorong Selatan tersebut terdapat pada ketinggian 300-400 m di atas permukaan laut, yang dipetakan meliputi luasan kurang lebih 100.000 ha (Reynders dan Schultz 1958). Secara kuantitatif apabila potensi fosfat alam Ayamaru yang dapat dieksploitasi diasumsikan 50\% dari luasan 100.000 ha dengan kedalaman $50 \mathrm{~cm}$, maka akan diperoleh pupuk fosfat alam sebanyak 200 juta ton.

Antonius Suparno urtuk penelitian disertasinya mengungkapkan peranan mikroorganisme dalam meningkatkan pertumbuhan bibit kakao, yan1juga dalam meningkatkan potensi batuan fosfat alam krandalit Papua. Penggunaan fosfat alam krandalit secara langsung telah dilakukan pada bibit kakao bersamaan dengan inokulasi Fungi Mikoriza Arbuskula (FMA). Inokulasi FMA dapat meningkatkan potensi fosfat alam krandalit Ayamaru yang diaplikasi pada bibit kakao (Suparno 2009; Suparno et al.2015). Keefektifan FMA dalam meningkatkan potensi fosfat alam Ayamaru dapat lebih ditingkatkan jika inokulasi FMA dikombinasikan dengan asam humat dan bakteri pelarut fosfat (Suparno et al.2012). Inokulasi FMA aplikasi fosfat 
alam Ayamaru juga meningkatkan pertumbuhan bibit kakao (Suparno et al.2014) dan bibit kopi (Suparno et al.2013; Suparno et al.2015).

Provinsi Jambi merupakan salah satu provinsi di Indonesia yang sebagian lahannya didominasi oleh lahan marjinal yaitu tanah ultisol. Berdasarkan Data Dinas Pertanian Tanaman Pangan (2010), Provinsi Jambi memiliki potensi tanah masam yang didominasi oleh ultisol dengan Luas 2.272.725 ha atau 44,56\% dari luasan Provinsi Jambi.

Jika dilihat dari luasnya, ultisol sangat berpotensi untuk dikembangkan sebagai lahan produktif untuk tanaman pertanian, namun untuk pemanfaatannya ultisol menghadapi beberapa kendala seperti sifat fisik dan biologi yang kurang baik, $\mathrm{pH}$ yang rendah, kandungan A1 dan Fe yang tinggi. Khusus unsur fosfor ketidaktersediaannya dalam tanah masam adalah akibat fiksasi fosfat oleh ion-ion A1 dan Fe membentuk Al-P dan Fe-P, sehingga tidak dapat diserap tanaman. Selain itu, berkembangnya tanah marjinal juga terjadi oleh adanya alih fungsi lahan pertanian untuk kegiatan di luar pertanian yakni kegiatan penambangan baik tambang minyak bumi maupun batubara. Di Provinsi Jambi terdapat 757.241,10 ha areal lzin Usaha Penambangan (IUP) (Dinas Sumber Daya Energi dan Mineral 2010) sehingga kemungkinan besar lahan bekas tambang minyak bumi dan batu bara juga sangat luas, dan dapat dimanfaatkan untuk ditanami berbagai tanaman.

Baik lahan ultisol maupun lahan bekas tambang batu bara mempunyai tingkat kesuburan yang rendah dan masalah dalam penyerapan air, akibatnya tanaman akan mengalami cekaman kekeringan pada musim kemarau sehingga perlu dilakukan kegiatan untuk memperbaikinya. Reklamasi merupakan kegiatan yang dilakukan untuk memperbaiki lahan-lahan marjinal (ultisol dan pasca penambangan) yang kemudian dilanjutkan dengan kegiatan revegetasi. Revegetasi sendiri bertujuan untuk memulihkan kondisi fisik, kimia, dan biologis tanah tersebut. Namun, upaya perbaikan dengan cara ini masih dirasakan kurang efektif karena tanaman secara umum kurang beradaptasi pada lingkungan ekstrim, termasuk bekas lahan tambang. Untuk mengatasi keadaan tersebut dapat dilakukan dengan beberapa cara yaitu : 1) penambahan pembenah tanah seperti kapur dan asam humik. 2) penggunaan jenis tanaman yang toleran 
terhadap aluminium yang merupakan adaptasi tanaman terhadap kendala pada tanah ultisol, 3) penggunaan mikroorganisme tanah yang potensial dan ramah lingkungan yang sering disebut sebagai pupuk hayati yang terlebih dahulu diseleksi pada kondisi Al tinggi. Mikroorganisme tanah tersebut antaralain : Fungi Mikoriza Arbuskula (FMA), mikroorganisme pelarut fosfat (PSB) dan bakteri penambat nitrogen (Azospirillum).

Salah satu alternatif untuk mengatasi masalah tersebut adalah dengan pemanfaatan mikroorganisme yang bermanfaat yaitu Fungi Mikoriza Arbuskular (FMA) yang mampu bersimbiosis dengan hampir semua jenis tanaman, maka tanaman akan terbantu dalam pengambilan air dan unsur hara pada tanah yang miskin unsur hara seperti pada tanah bekas tambang minyak bumi dan batu bara serta ultisol. Perkembangan FMA pada setiap areal lahan berbeda-beda dan pengaruhnya terhadap tanaman juga berbeda sehingga diperlukan isolat FMA yang cocok terhadap lingkungan dan tanaman yang di budi dayakan. Berdasarkan potensi dan permasalahan yang diungkap di atas, dalam penelitian disertasinya berlokasi di Jambi, Elis Kartika menunjukkan bahwa bibit kelapa sawit yang bersimbiosis dengan FMA memberikan tanggap pertumbuhan dan serapan hara bibit yang lebih tinggi dibandingkan dengan bibit tanpa FMA pada setiap cekaman kekeringan. Bibit kelapa sawit yang bersimbiosis dengan FMA lebih efisien dalam penggunaan air dibandingkan dengan bibit tanpa FMA (Kartika 2006; Yahya et al. 2006). Dari penelitian tersebut diperoleh bahwa inokulum campuran isolat yang mengandung masing-masing isolat tunggalnya merupakan isolat yang lebih efektif dalam meningkatkan pertumbuhan dan serapan $\mathrm{P}$ di tanah ultisol bekas hutan dibandingkan masing-masing isolat tunggalnya (Kartika et al.2006).

Dari beberapa penelitian yang sudah dilalankan, telah diperoleh teknologi yang efektif, ramah lingkungan, murah, dan berkelanjutan. Dari hasil penelitian Kartika et al. (2009) diperoleh 4 jenis FMA indigen yang berasal dari lahan bekas tambang batubara. FMA tersebut kemudian diuji keefektivannya pada tanaman jarak pagar (Kartika, et al. 2010) dan diperoleh hasil bahwa FMA jenis Glomus sp 3 merupakan jenis yang paling efektif dan kompatibel dengan tanaman 
jarak pagar tersebut. Selanjutnya untuk memerifikasi hasil penelitian tersebut, Kartika et al. (2011) melanjutkan penelitiannya dengan menguji jenis FMA tersebut langsung di lahan bekas tambang batubara. Dari penelitian tersebut diperoleh hasil bahwa tanaman jarak pagar yang bersimbiosis dengan FMA menunjukkan pertumbuhan dan hasil lebih tinggi dibandingkan dengan tanaman tanpa inokulasi FMA pada lahan bekas tambang batu bara. Perlakuan FMA yang dikombinasikan dengan $50 \%$ dosis anjuran pupuk $\mathrm{P}$ memberikan pertumbuhan dan hasil tanaman jarak pagar yang terbaik di lahan bekas tambang batu bara. Tanaman yang bersimbiosis dengan FMA dan ditanam pada lahan bekas tambang batu bara dapat lebih efisien dalam pemakaian pupuk $\mathrm{P}$ sampai 50\% dari dosis rekomendasi.

Margarettha dan Kartika (2009) meneliti tentang pengembangan teknologi mikoriza indigenous pada bibit karet untuk revegetasi lahan bekas tambang minyak bumi. Dari hasil penelitian ini diperoleh bahwa FMA indigen efektif dan kompatibel dengan bibit karet dan mampu meningkatkan pertumbuhan bibit karet di lahan bekas tambang minyak bumi.

Suryanto et al. (2011) meneliti tentang pengembangan teknologi pupuk hayati indigen untuk bibit karet dalam rangka revegetasi lahan tercemar hidrokarbon aromatik polisiklik. Penelitian ini menunjukkan bahwa teknologi pupuk hayati indigen yang berupa FMA mampu meningkatkan pertumbuhan bibit karet di media revegetasi lahan tercemar hidrokarbon aromatik polisiklik. Suryanto et al. (2012) melanjutkan penelitian tersebut dan diperoleh hasil bahwa FMA indigen tersebut mampu meningkatkan pertumbuhan tanaman karet di lahan tercemar hidrokarbon aromatik polisiklik.

Kartika et al. (2012), mencoba meneliti lebih lanjut keragaan pertumbuhan bibit kelapa sawit pada aplikasi FMA dan pupuk P di lahan bekas tambang batubara. Dari hasil penelitian tersebut diperoleh bahwa pemberian berbagai jenis mikoriza, dosis pupuk $\mathrm{P}$ serta interaksi antara pemberian berbagai jenis mikoriza dan pupuk $\mathrm{P}$ mampu meningkatkan keragaan pertumbuhan bibit kelapa sawit umur 3 bulan di tanah bekas tambang batubara pada pembibitan awal. Pemberian mikoriza jenis Glomus sp-3 dan $75 \%$ dosis anjuran pupuk $\mathrm{P}$ mampu meningkatkan keragaan pertumbuhan bibit kelapa sawit 
umur 3 bulan yang terbaik di tanah bekas tambang batubara pada pembibitan awal.

Kartika et al. (2013) meneliti peranan FMA indigen hasil penelitian Kartika et al. (2009) terhadap bibit karet yang ditanam pada tanah asal tambang batubara. Hasil penelitian menunjukkan bahwa pemberian berbagai jenis mikoriza dan jenis klon karet serta interaksi antara pemberian berbagai jenis mikoriza dan jenis klon karet mampu meningkatkan pertumbuhan bibit karet umur 5 bulan yang ditanam di tanah bekas tambang batubara pada pembibitan utama. Bibit klon karet RRIC-100 yang diinokulasi isolat mikoriza jenis Glomus sp-16 mampu meningkatkan pertumbuhan bibit karet umur 5 bulan yang terbaik di tanah bekas tambang batubara.

Kartika et al. (2013) meneliti kajian FMA dan berbagai pupuk organik terhadap bibit kelapa sawit di pembibitan utama. Hasil penelitian menunjukkan bahwa pemberian berbagai jenis mikoriza dan jenis pupuk organik serta interaksi antara pemberian berbagai jenis mikoriza dan jenis pupuk organik mampu meningkatkan pertumbuhan bibit kelapa sawit umur 5 bulan yang ditanam di tanah marjinal (ultisol) pada pembibitan utama. Pemberian mikoriza jenis Glomus sp16 dan pupuk kompos kotoran sapi mampu meningkatkan pertumbuhan bibit kelapa sawit umur 5 bulan yang terbaik di tanah marjinal (ultisol) pada pembibitan utama.

Selanjutnya, Kartika et al. (2014) melanjutkan penelitian tahun 2013 dengan mengkaji peranan FMA indigen tersebut dengan pupuk organik kompos kotoran sapi terhadap tanaman kelapa sawit belum menghasilkan (TBM I) di lahan marjinal (ultisol). Hasil penelitian menunjukkan bahwa pemberian mikoriza dan berbagai dosis pupuk kompos kotoran sapi serta interaksi artara pemberian mikoriza dan berbagai dosis pupuk kompos kotoran sapi mampu meningkatkan pertumbuhan tanaman kelapa sawit belum menghasilkan (TBM 1) yang ditanam di lahan marjinal. Pemberian mikoriza dan pupuk kompos kotoran sapi dengan dosis $75 \%$ dari dosis rekomendasi (15 $\mathrm{kg} /$ tanaman) mampu meningkatkan pertumbuhan tanaman kelapa sawit belum menghasilkan (TBM 1) yang terbaik di lahan marjinal. 
Gusniwati et al.(2015) mengisolasi dan mengidentifikasi spesies cendawan mikoriza arbuskular di bawah tegakan tanaman duku serta mempelajari peranannya dalam pertumbuhan bibit duku (Lansium domesticum Corr). Dari hasil-hasil penelitian tersebut terbukti bahwa pemanfaatan FMA dan pupuk organik pada tanaman perkebunan terbukti meningkatkan pertumbuhan tanaman. Penelitian sebelumnya juga sudah membuktikan bahwa FMA mampu memperbaiki penyerapan hara dan meningkatkan pertumbuhan tanaman. FMA menginfeksi akar tanaman kemudian memproduksi jalinan hifa secara intensif sehingga tanaman yang bermikoriza akan mampu meningkatkat kapasitasnya dalam penyerapan unsur hara. Unsur hara yang diserap tanaman yang terinfeksi FMA terutama $\mathrm{P}$, karena $\mathrm{P}$ diperlukan dalam jumlah yang relatif banyak, tetapi ketersediaannya terutama pada tanah-tanah masam menjadi terbatas sehingga sering kali menjadi faktor pembatas dalam meningkatkan produksi tanaman. Selain itu, akar yang terinfeksi mikoriza mampu meningkatkan penyerapan $\mathrm{NH}_{4}{ }^{+}$dan $\mathrm{NO}_{3}{ }^{-}$serta $\mathrm{Mg}$.

Dengan pola penanganan yang serupa terhadap lingkungan tumbuh suboptimal, Panca Dewi Manu Hara Karti memulai dengan penelitian disertasi pada tanaman pakan ternak. Karti et al. (2012) mempelajari mekanisme toleransi Setaria splendida terhadap keracunan $\mathrm{Al}$ dan peranan mikroorganisme tanah dalam meningkatkan kelarutan fosfat tanah. Pada berbagai penelitian lanjutan telah dilakukan penelitian guna pengembangan teknologi produksi pada kondisi lingkungan cekaman kekeringan, meliputi :

1. Pengaruh pemberian fungi mikoriza arbuskula terhadap pertumbuhan dan produksi rumput Setaria splendida Stapf yang mengalami cekaman kekeringan (Karti 2004).

2. Peranan FMA dalam meningkatkan produktivitas, kualitas nutrisi, dan mekanisme toleransi terhadap kekeringan pada Stylosanthes seabrana, (Karti et al. 2012)

3. Adaptasi legum pohon Macropthilium bracteatum yang diinokulasi dengan fungi mikoriza arbuskular (FMA) saat cekaman kekeringan (Sowmen et al. 2014) 
4. Adaptasi fisiologi dan produksi biomassa Macroptilium bracteatum yang diinokulasi dengan FMA pada kondisi kekeringan (Sowmen et al. 2012).

Penelitian-penelitian lainnya dilakukan dalam mengembangkan teknologi produksi pada kondisi suboptimal lahan pasca tambang, yakni (1) pengembangan rumput Brachiario humidicolc dan legum pohon Glyrisidia sepium pada lahan pasca tambang semen PT. Indocement Tunggal Prakasa (Karti dan Sofran 2O14), (2) penggunaan mikroorganisme tanah, asam humat, tanaman pakan rumput, dan legum pada lahan marjinal dan terdegradasi (bekas tambang emas) di Indonesia (Karti 2009).

Pada jenis tanaman dan kondisi lingkungan media tumbuh yang lain, dalam penelitian disertasinya, Iwan Sasli mengungkapkan pula peranan FMA pada tanaman lidah buaya (Aloe vera), pada tanah histosol atau gambut di daerah Pontianak, Kalimantan Barat. Aplikasi FMA juga berhasil memperbaiki pertumbuhan dan kualitas tanaman lidah buaya serta meningkatkan efisiensi pemupukan di tanah gambut (Sasli et al. 2008) . Berbeda dengan penelitian yang dilakukan Kartika tersebut di atas, Iwan Sasli melalui penelitian-penelitiannya yang juga memanfaatkan FMA yang spesifik tanah gambut dengan faktor cekaman lingkungan, yakni salinitas pada berbagai jenis tanaman pangan. Setelah penelitian disertasinya, penelitian lebih lanjut diawali dengan memperdalam pemahaman terhadap karakteristik tanah gambut setempat, mengeksplorasi isolate-isolat FMA yang adaptif dan potensial bagi tanah gambut dan berbagai jenis tanaman pangan, yang bercekaman spesifik lokal, yakni salinitas. Penelitian dan pengembangan selanjutnya berkaitan dengan sumber daya terbarukan yang dilakukan oleh Iwan Sasli diringkaskan sebagai berikut.

1. Melakukan kajian-kajian pemanfaatan mikroorganisme khususnya fungi mikoriza arbuskula untuk meningkatkan serapan hara, ketahanan tanaman terhadap kekeringan, dan ketahanan tanaman terhadap soil pathogen. (Sasli 1999; Sasli 2000; Sasli 2001; Sasli 2003)

2. Melakukan kajian karakteristik tanah gambut dengan segala keterbatasannya (Sasli 2006; Sasli 2009) 
3. Mempelajari sisi positif tanah gambut yang selama ini dianggap memiliki banyak kendala bila dimanfaatkan untuk budi daya tanaman. Sisi positif itu adalah banyaknya fungi mikoriza arbuskula (FMA) yang berasosiasi dengan vegetasi-vegetasi pionir di tanah gambut, sehingga vegetasi tersebut mampu hidup pada tanah gambut dengan segala keterbatasannya. (Sasli 2005; Sasli 2008; Sasli 2009)

4. Mengeksplorasi lebih jauh keberadaan fungi mikoriza arbuskula pada berbagai keadaan bentang lahan tanah gambut sekaligus mengkarakteristik sifat fisik dan kimia gambut. Selanjutnya dihitung kerapatan spora pada lahan yang diamati, diidentifikasi jenis mikorizanya, diuji tingkat infektivitasnya terhadap tanaman inang sehingga ditemukan spora mikoriza unggul. (Sasli dan Radian 2010; Sasli dan Radian 2011)

5. Mengupayakan perbanyakan mikoriza arbuskula hasil temuan dari vegetasi pionir gambut untuk dikembangkan sebagai pupuk hayati (Sasli dan Radian 2011) yang dapat dimanfaatkan oleh masyarakat tani untuk mengatasi persoalan kelangkaan pupuk anorganik dan dampak yang ditimbulkannya terhadap lingkungan.

6. Melakukan perbaikan dan diversifikasi bahan pembawa (carrier) pupuk hayati dengan memanfaatkan sumber bahan organik dan anorganik yang kelimpahannya banyak secara insitu, murah secara ekonomi, adaptable terhadap FMA dan applicable dalam pemanfaatannya (Sasli dan Radian 2013)

7. Peneliti telah membuktikan bahwa pupuk hayati FMA yang dihasilkan mampu untuk mengatasi cekaman salinitas pada tanaman pangan (kedelai) skala rumah kaca (Sasli dan Radian 2014).

Berdasarkan beberapa penelitian di atas yang telah dilakukan terhadap mikroorganisme potensial, dapat disimpulkan beberapa hal sebagai berikut:

1. Mikroorganisme potensial yaitu fungi mikoriza arbuskula (FMA) asal spesifik gambut Kalimantan Barat dapat dikembangan serta 
layak digunakan sebagai bahan dasar pupuk hayati dengan tingkat propagul infektif nya yang tinggi.

2. Pupuk hayati mikoriza arbuskula yang dihasilkan mampu meningkatkan pertumbuhan dan hasil tanaman kedelai dan jagung di tanah gambut.

3. Aplikasi pupuk hayati FMA yang dihasilkan mampu meningkatkan efisiensi penggunaan pupuk fosfat sehingga akan menekan biaya produksi tanaman pangan di lahan marginal termasuk lahan gambut.

4. Aplikasi pupuk hayati FMA spesifik gambut Kalimantan Barat juga meningkatkan ketahanan tanaman kedelai terhadap cekaman salinitas, baik skala rumah kaca maupun di lapangan.

5. Pemanfaatan FMA spesifik lokasi gambut Kalimantan Barat dan pengembangannya menjadi pupuk hayati menjadi salah satu upaya dalam pemanfaatan sumber daya terbaharukan dalam teknologi produksi tanaman guna mendukung sistem pertanian berkelanjutan.

Interaksi faktor lingkungan abiotik dan biotik. Peranan FMA yang telah diungkapkan di atas secara umum akan memperbaiki lingkungan tumbuh abiotik, di antararrya peranan dalam ketersediaan dan penyerapan hara terutama fosfat, meningkatkan kemampuan adaptasi tanaman terhadap cekaman abiotik kekeringan, dan cekaman abiotik toksisitas logam berat. Umumnya, terdapat anggapan bahwa perbaikan-perbaikan morfologi dan fisiologi tanaman terutama perkaranya yang disebabkan oleh inokulasi FMA tersebut mengakibatkan tanaman tumbuh jagur, sehingga lebih mampu mengatasi cekaman lingkugan biotik, yakni patogen, penyebab penyakit tanaman. Walaupun demikian, hasil penelitian disertasi Yenni Bakhtiar mengungkapkan sisi lain dari interaksi antara factor lingkungan abiotik, faktor lingkungan biotik dan tanaman kelapa sawit (Bakhtiar et al. 2010 dan 2012).

Bakhtiar et al. (2010) mengungkapkan bahwa di dalam spora FMA yang diperoleh terdapat beberapa jenis bakteri yang hidup bersama FMA atau disebut bakteri endosimbiotik mikoriza yang 
didominasi oleh bakteri Gram positif. Beberapa isolate bakteri yang diisolasi dari spora FMA dari rizosfir kelapa sawit mampu meningkatkan persentase berkecambah spora FMA dan sekaligus menghambat pertumbuhan patogen Ganoderma boninense in vitro. Pada penelitian in vivo, inokulasi FMA dikombinasikan dengan bakteri endosimbiotik mikoriza Bacillus subtilis B10 pada bibit kelapa sawit mengeluarkan senyawa (Gambar 1) yang dapat menginduksi bibit kelapa sawit untuk menghasilkan kumpulan senyawa aktif yang berperan dalam meningkatkan daya adaptasi bibit kelapa sawit (Gambar 2a dan b) tehadap cekaman biotik patogen $G$. boninense (Bakhtiar et al.2012). Penelitian lanjutan masih berlangsung untuk memastikan apakah senyawa aktif yang dihasilkan oleh bakteri endosimbiotik mikoriza B. substilis B 10 secara in vitro yaitu 2-(4aminophenoxy)-6- methyl-tetrahydro-2H-pyran-3,4,5-triol yang memiliki daya hambat besar terhadap pathogen $G$. boninense pada uji in vitro juga terdapat di dalam kumpulan senyawa aktif yang dihasilkan oleh bibit kelapa sawit secara in vivo yang terinduksi oleh inokulasi FMA dan bakteri endosimbiotik mikoriza tersebut di atas (Bakhtiar 2011).

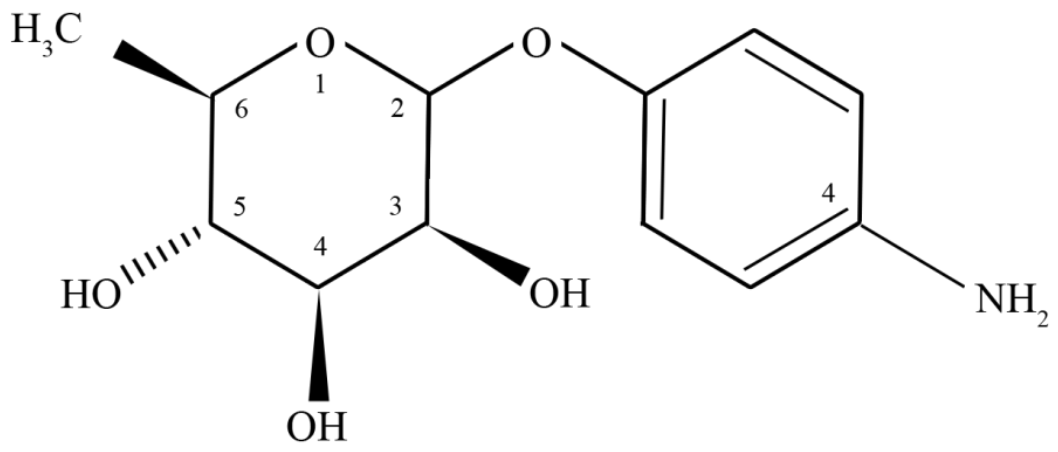

Gambar 1 Postulasi struktur kimia senyawa aktif dari bakteri Bacillus subtilis B 10 (Bakhtiar 2011) 


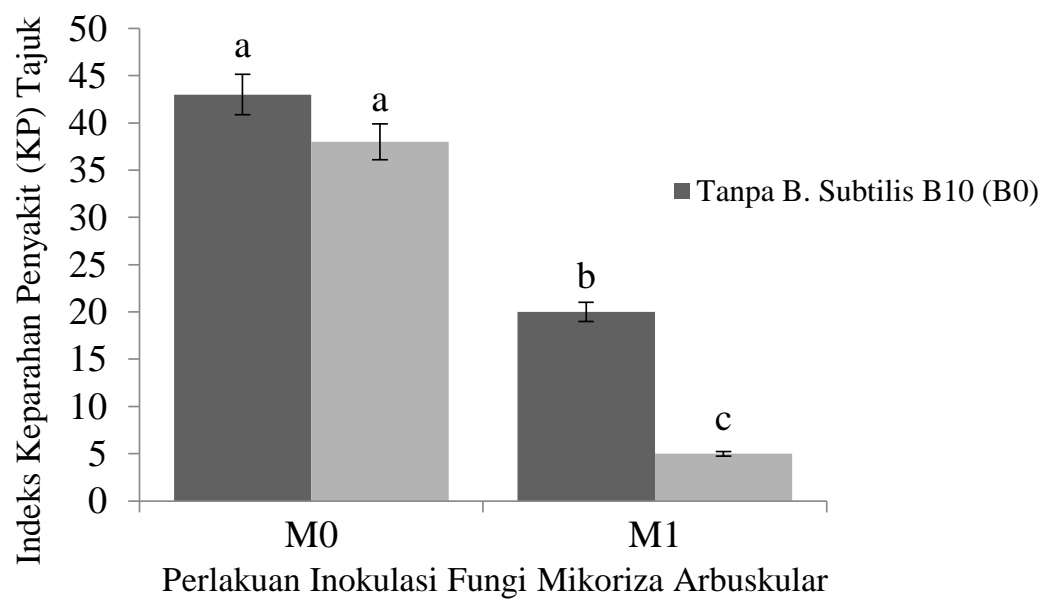

Gambar 2a Persentase indeks Keparahan Penyakit (KP) tajuk bibit kelapa sawit 52 MST. Inokulasi FMA dan bakteri Bacillus subtilis B10 (M1B1 memberikan persentase KP yang paling rendah. Huruf yang sama pada grafik tidak berbeda nyata dengan uji Duncan pada taraf 5\% (Bakhtiar 2011). 

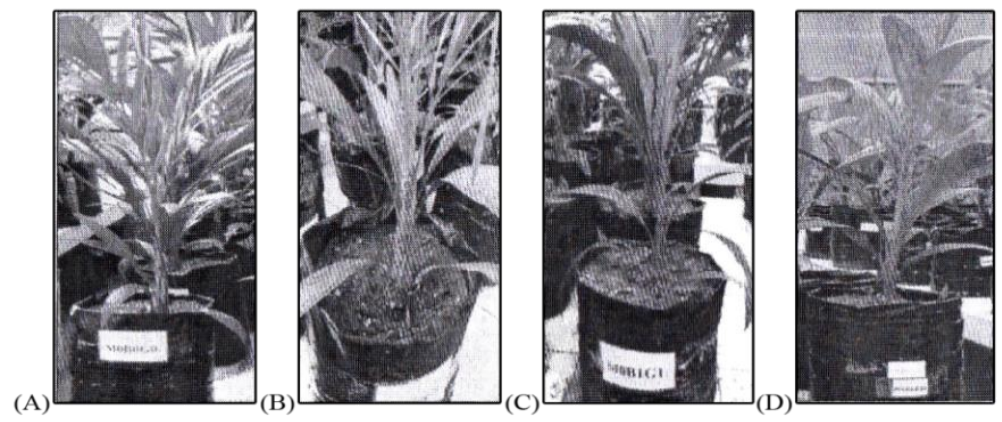

Gambar 2b Pertumbuhan bibit kelapa sawit 52 MST (A) bibit tanpa inokulasi FMA, bakteri endosimbiotik mikoriza $B$. subtilis 810 dan G. boninense (M0B0G0), (B) bibit tanpa inokulasi FMA dan bakteri endosimbiotik mikoriza $B$. subtilis B10 dengan inokulasi $G$. boninense (M0B0G0), terlihat tumbuh tubuh buah Ganoderma, daun, dan batang berwatna coklat dan mengering, (C) bibit dengan inokulasi bakteri endosimbiotik mikoriza B. subtilis B10 dan $G$. boninense, di mana daun terlihat coklat dan mengering (MOB1G1) (D) bibit dengan inokulasi FMA, bakteri endosimbiotik mikoriza B. subtilis B10 dan patogen $G$. boninense (MlB1G1) walaupun ada patogen bibit tumbuh lebih sehat (Bakhtiar 2011). 


\section{DAFTAR PUSTAKA}

Amat K S. 1991. Pengaruh Kotoran Sapi terhadap Kelarutan PKrandalit pada Tanah Mineral Masam Thesis] Bogor: Fakultas Pascasarjana IPB.

Anonim. 2012. Padi berkadar besi tinggi dari kedelai, upaya mengatasi anemia. Kompas, 22 November 2012. Jakarta. Halaman 13.

Aryanti M, S Yahya, Kukuh M, Suwarto, Hasril HS. 2015b. Peran Tanaman Penutup Tanah Nephrolepis biserrata terhadap Neraca Air di Perkebunan Kelapa Sawit Lampung Selatan. Jurnal Penelitian Kelapa Sawit, 23 (2): (in press).

Bakhtiar Y. 2011. Peran Fungi Mikoriza Arbuskular dan Bakteri Endosimbiotik Mikoriza dalam Meningkatkan Daya Adaptasi Bibit Kelapa Sawit (Elaeis guineensis Jacq) terhadap Cekaman Biotik Ganoderma boninense Pat. Disertasi Sekolah Pascasarjana Institut Pertanian Bogor.

Chotimah, Hastin E N, Ardianor, Ichriani G I. 2014. Introduksi Teknologi Inovasi Ambul Untuk Budi Daya Tanaman Sayuran Di Kalimantan Tengah. Udayana mengabdi. Jurnal Pengabdian Kepada Masyarakat ISSN 1412-0925, 13(1).

Dinas Pertanian Tanaman Pangan. 2010. Tanah Ultisol Provinsi Jambi. Jambi.

Gromikora N, S Yahya, Suwarto. 2014. Permodelan pertumbuhan dan produksi kelapa sawit pada berbagai taraf penunasan pelepah. Jumal Agronomi Indonesia 42 (3): 228-235.

Gusniwati, Lizawati, Kartika. 2015. Isolasi dan Identifikasi Spesies Cendawan Mikoriza Arbuskula di Bawah Tegakan Tanaman Duku serta Peranannya dalam Pertumbuhan Bibit Duku (Lansium domesticum Corr). Laporan Penelitian Hibah Bersaing Tahun I. Fakultas Pertanian, Universitas Jambi.

Hopkins WG. 1995. Introduction to Plant Physiology. The University of Westem Ontario. Jhon Wiley and Sons, INC. 
Karti P D M H. 2004. Pemberian Fungi Mikoriza Arbuskula terhadap Pertumbuhan dan Produksi Rumput Setaria splendida Stapf yang Mengalami Cekaman Kekeringan. Media Petenakan, 27 (2): 63-68.

Kartika 8.2006. Tanggapan Pertumbuhan, Serapan Hara dan Karakter Morfofi siologis terhadap Cekaman Kekeringan pada Bibit Kelapa Sawit yang Bersimbiosis dengan CMA. Disertasi. S ekol ah P ascasarj ana. Institut Pertanian Bogor.

Pembengo W, Handoko, Suwarto.2012. Efisiensi penggunaan cahaya matahari oleh tebu pada berbagai tingkat pemupukan nitrogen dan fospor. Jumal Agornomi Indonesia 40 (3): 211-217.

Sasli I. 2009. Pemanfaatan MikorizaArbuskula asal Kalimantan Barat sebagai Pupuk Hayati pada Tanaman Jagung di Tanah Gambut. Penelitian Dana DIpA Fakultas pertanian Untan.

Sowmen S, L Abdullah, P D M H Karti, D Sopandie. 2012. Physiological Adaptation and Biomass Production of Macroptilium bracteatum Inoculated with AMF in Drought Condition. Media Peternakan, 2012.

Suwarto. 2015. Production of organic matter in situ for sustainability high productivity of cassava field. Int,l Conference on Biotechnology, Nanotechnolgy \& Environmental Engineering (ICBNE,15) at Bangkok April 22-23, Bangkok (Thai land).

Yenni A, S Yahya, Kukuh M, Sudradjat, Eddy SS.2015b. Peran Tanaman Penutup Tanah terhadap Neraca Hara N, p, K di Perkebunan Kelapa Sawit Menghasilkan di Lampung Selatan. J. Penel. Kelapa Sawit, 23 (2) (in press) 